\title{
ANALISIS PENDEKATAN GAME THEORY UNTUK PEMILIHAN KANAL PADA JARINGAN RADIO KOGNITIF
}

\author{
Norma Amalia*), Ifaz Fachrul Hindami, dan Ade Wahyudin \\ Program Studi S1 Teknik Telekomunikasi, Institut Teknologi Telkom Purwokerto \\ Jl. D. I. Panjaitan no. 128 Purwokerto, Indonesia \\ ${ }^{*}$ E-mail:norma@ittelkom-pwt.ac.id
}

\begin{abstract}
Abstrak
Spektrum frekuensi pada jaringan komunikasi nirkabel bersifat terbatas. Oleh karena itu diperlukan solusi dalam mengoptimalkan penggunaan spektrum frekuensi, salah satunya adalah dengan penggunaan jaringan radio kognitif. Spektrum pada jaringan radio kognitif bersifat heterogen, yaitu terdiri dari Primary User (PU) dan Secondary User (SU). Pada jaringan radio kognitif, SU dapat menggunakan kanal yang sama dengan PU selama SU tidak menyebabkan interferensi yang dapat menurunkan unjuk kerja dari PU. Salah satu metode yang dapat digunakan untuk meminimalkan interferensi adalah dengan metode pemilihan kanal menggunakan pendekatan game theory. Dengan metode ini, interferensi SU terhadap PU dapat diminimalkan. Pada penelitian ini, dianalisis kinerja dari metode pemilihan kanal menggunakan pendekatan game theory. Unjuk kerja jaringan radio kogntif dapat ditingkatkan dengan dengan menggunakan pemilihan kanal dengan pendekatan game theory. Pada jaringan radio kognitif tanpa keberadaan PU, nilai throughput tanpa pendekatan game theory PU sebesar 20,28 bps sedangkan dengan pendekatan game theory sebesar 23,58 bps. Nilai rata-rata SIR tanpa pendekatan game theory sebesar 18,08 dB sedangkan dengan pendekatan game theory sebesar $21,4 \mathrm{~dB}$.
\end{abstract}

Kata kunci: Radio Kognitif, Game theory, SIR, Throughput

\begin{abstract}
The frequency spectrum of wireless communication networks is limited. Therefore a solution in optimizing the use of the frequency spectrum is needed, one of which is the use of cognitive radio networks. Spectrum on cognitive radio network is heterogeneous, which consists of Primary User (PU) and Secondary User (SU). In cognitive radio networks, SU can use the same channel with PU during SU does not cause interference that may decrease the performance of PU. One method that can be used to minimize interference is by channel selection method using game theory approach. With this method, SU interference to PU can be minimized. In this study, analyzed the performance of channel selection method using game theory approach. Cognitive radio network performance can be improved by using channel allocation with game theory approach. In cognitive radio network without the existence of PU, average network throughput without game game theory approach is $20,28 \mathrm{bps}$ while with game theory approach is $23,58 \mathrm{bps}$. The average value of SIR without game theory approach is $18,08 \mathrm{~dB}$, while the game theory approach is $21,4 \mathrm{~dB}$.
\end{abstract}

Keywords: Cognitive Radio, Game theory, SIR, Throughput

\section{Pendahuluan}

Perkembangan teknologi secara umum akan terus berkembang memenuhi kebutuhan manusia yang tidak terbatas. Begitu juga teknologi telekomunikasi yang saat ini sudah menjadi kebutuhan primer. Salah satu pengembangan teknologi pada sistem telekomunikasi adalah teknologi nirkabel. Komunikasi nirkabel memanfaatkan gelombang radio pada spektrum frekuensi tertentu. Keberadaan spektrum frekuensi sifatnya terbatas. Disisi lain, kebutuhan akan penggunaan spektrum frekuensi semakin meningkat. Untuk itu diperlukan sebuah paradigma baru dalam pemanfaatan spektrum frekuensi. Salah satu paradigma sistem komunikasi baru yang mampu mengoptimalkan spektrum frekuensi adalah jaringan radio kognitif [1]. Pada jaringan radio kognitif, terdapat pengguna terlisensi atau Primary User (PU) dan pengguna tidak terlisensi atau Secondary User (SU). Pengguna terlisensi merupakan pemilik utama spektrum yang ada, sedangkan pengguna tidak terlisensi merupakan pengguna dari jaringan radio kognitif yang dapat menggunakan spektrum frekuensi milik pengguna terlisensi.

Sifat radio kognitif yang mampu menyesuaikan parameter transmisi sesuai dengan kondisi sekitarnya membuat radio 
kognitif mampu memiliki fitur spectrum sharing [2]. Dengan spectrum sharing, spektrum bisa digunakan secara efisien karena SU bisa berada pada kanal yang sama dengan PU selama tidak menyebabkan interferensi yang berlebihan [3][7]. Salah satu metode yang dapat digunakan untuk meminimalkan interferensi adalah dengan menggunakan metode pemilihan kanal. Beberapa penelitian tentang radio kognitif telah dilakukan pada penelitian [5]-[9], sedangkan penelitian tentang pemilihan kanal pada jaringan radio kognitif telah dilakukan pada penelitian [10]-[14]. Pada penelitian [6], dibahas tentang potential game dengan kendali daya untuk menjamin kondisi terbaik pada jaringan radio kogntif. Pada penelitian [9], disimulasikan kendali daya berdasarkan pencapaian feasible solution sehingga target signal to interference ratio (SIR) dapat dipenuhi. Pada penelitian [7], dipaparkan tentang game theory dalam jaringan radio kognitif, salah satunya adalah tentang potential game. Dalam permainan ini, strategi pemain adalah memilih satu kanal dari beberapa kanal untuk transmisi, dan pemain dalam band yang sama saling menginterferensi satu sama lain. Untuk mengurangi interferensi timbal balik, payoff/utility function didefinisikan sebagai total interferensi yang tidak hanya disebabkan oleh pemain lain tetapi juga yang menyebabkan interferensi ke pemain lain

Pada penelitian ini dilakukan simulasi tentang pemilihan kanal pada jaringan radio kognitif dengan pendekatan game theory. Pemilihan kanal digunakan untuk menentukan SU berada pada kanal tertentu. Dengan pendekatan game theory, kanal yang ditempati oleh SU adalah kanal dengan interferensi minimum, sehingga unjuk kerja dari SU dan PU terjaga. Unjuk kerja dari pengguna dapat dilihat dari Signal to Interference Ratio (SIR) dan throughput.

\section{Metode}

\subsection{Jaringan Radio Kognitif}

Pada tahap awal, disimulasikan jaringan ad-hoc radio kognitif dengan beberapa pasang SU dan PU seperti dapat dilihat pada Gambar 1. Luas area simulasi adalah daerah persegi dengan panjang sisi $1000 \mathrm{~m}$. Topologi yang digunakan terdiri dari Transmitter PU (tx_PU), Receiver PU (rx_PU), Transmitter SU (tx_SU) dan Receiver SU (rx_SU). Langkah selanjutnya adalah dengan mensimulasikan metode pemilihan kanal menggunakan pendekatan game theory. Ada dua kondisi kanal yang dipertimbangkan dalam penelitian ini, yaitu kanal yang terdiri dari SU saja, dan kanal yang terdiri dari SU dan PU.

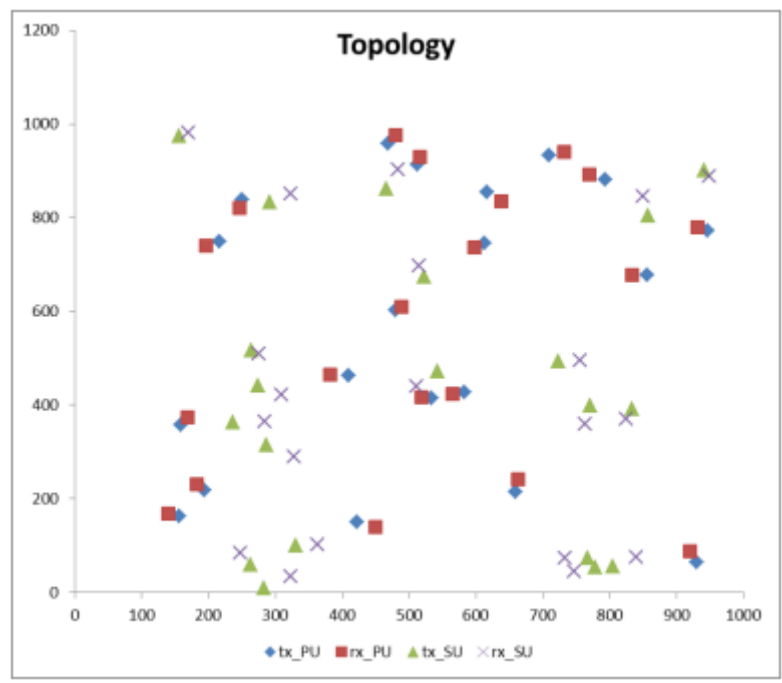

Gambar 1. Topologi Jaringan Radio Kognitif

\subsection{Pendekatan Game Theory untuk Pemilihan Kanal}

Game theory merupakan algoritma yang mampu menganalisis strategi antar pemain dalam situasi kompetitif untuk mencapai kondisi nash equilibrium. Nash equilibrium adalah sebuah kondisi terbaik dengan strategi yang digunakan oleh setiap pemain [6] [7]. Strategi dikatakan terbaik ketika sudah tidak ada lagi pemain yang mengganti strateginya. Dalam konteks penelitian ini pemain terdiri dari pengguna jaringan radio kognitif atau SU, strategi yang digunakan merupakan pemilihan kanal untuk SU pada jaringan sehingga mencapai kondisi nash equilibrium.

Game theory merupakan alat matematika yang menganalisis interaksi strategis di antara banyak pengambil keputusan. Tiga komponen utama dalam model permainan bentuk strategis adalah [7]:

a. satu set terbatas players (pemain), dilambangkan dengan $N$

b. satu set actions (tindakan, dilambangkan dengan $\boldsymbol{A}_{i}$, untuk setiap pemain $i$

c. payoff/utility function, dilambangkan dengan, $u_{i}: \boldsymbol{A} \rightarrow$ $\mathbf{R}$, yang mana mengukur hasil untuk pemain $i$ yang ditentukan oleh tindakan semua pemain, A $=\mathrm{x}_{\mathrm{ieN}} \boldsymbol{A}_{i}$

Mengingat definisi dan notasi di atas, permainan strategis sering dilambangkan oleh $\langle\boldsymbol{N},(\boldsymbol{A} i),(u i)\rangle$. Karena pengguna dalam jaringan radio kognitif dapat bersaing untuk sumber daya spektrum terbatas, kita dapat memodelkan interaksi di antara mereka sebagai game. Persamaan utility function untuk pemilihan kanal dapat dilihat pada Persamaan 1.

$\mathrm{ul}_{\mathrm{i}}\left(\mathrm{a}_{\mathrm{i}}, \mathrm{a}_{-\mathrm{i}}\right)=-\sum_{\mathrm{j}=1, \mathrm{j} \neq \mathrm{i}}^{\mathrm{N}} \mathrm{G}_{\mathrm{ij}} \mathrm{P}_{\mathrm{i}} \delta_{c j} \mathrm{ci}-\sum_{\mathrm{j}=1, \mathrm{j} \neq \mathrm{i}}^{\mathrm{N}} \mathrm{G}_{\mathrm{ij}} \mathrm{P}_{\mathrm{i}} \delta_{\mathrm{cj} \text { ci }}$ 
Dimana $\mathrm{P}_{\mathrm{i}}$ merupakan daya pancar pemancar SU ke $i . \mathrm{G}_{\mathrm{ij}}$ merupakan link gain antara pemancar SU ke-j dan penerima SU ke-i. $\delta_{\text {cj ci }}$ adalah fungsi interferensi yang mengindikasikan apakah kanal ci dan kanal cj adalah sama. Jika kanal ci $=$ cj, maka nilai $\delta_{\text {cj ci }}=1$ dan jika kanal ci $\neq$ cj maka nilai $\delta_{\text {cj ci }}=0$.

Persamaan 1 merupakan fungsi utilitas dari strategi pemilihan kanal. fungsi utilitas pada penelitian ini mempertimbangkan interferensi pada jaringan. Sehingga dengan fungsi utilitas pada persamaan 1 akan dicari kondisi dengan nilai interferensi paling rendah.

\subsection{Skenario Simulasi}

Simulasi dilakukan dengan jumlah SU yang bervariasi. Jumlah kanal sama dengan jumlah PU. Parameter input simulasi dapat dilihat pada Tabel 1 .

Tabel 1. Parameter Simulasi

\begin{tabular}{cll}
\hline No & Parameter & Nilai \\
\hline 1. & Luas Area & $1000 \mathrm{~m}^{2}$ \\
2. & Iterasi & 1000 \\
3. & Noise Power & $1 \mathrm{e}-13$ \\
4. & Daya Trasmitter & $0,0005 \mathrm{w}$ \\
5. & Daya PU & $0,0025 \mathrm{w}$ \\
6. & Lambda & 1 \\
7. & aTarget SIR & $20 \mathrm{~dB}$ \\
8. & Jumlah SU & bervariasi \\
9. & Jumlah PU & 30 \\
\hline
\end{tabular}

Pada penelitian ini, disimulasikan pemilihan kanal pada jaringan radio kognitif dengan pendekatan game theory dan tanpa pendekatan game theory. Skenario simulasi yang digunakan adalah sebagai berikut:

a. Jaringan radio kognitif tanpa pemilihan kanal game theory dan tanpa mempertimbangkan keberadaan PU

b. Jaringan radio kognitif tanpa pemilihan kanal game theory dan dengan mempertimbangkan keberadaan PU

c. Jaringan radio kognitif dengan pemilihan kanal game theory dan tanpa mempertimbangkan keberadaan PU

d. Jaringan radio kognitif dengan pemilihan kanal game theory dan dengan mempertimbangkan keberadaan PU

Parameter yang digunakan untuk melihat performa PU dan SU adalah Signal to Interference Ratio (SIR) dan throughput. Daya pancar transmitter dapat mempengaruhi nilai Signal to Interference Ratio (SIR). Jika terdapat lebih dari satu pengguna menggunakan kanal yang sama maka akan terjadi interferensi. Persamaan SIR pada penerima SU ke- $i$ dapat diekspresikan pada persamaan 2 .

$$
\gamma_{i}=\frac{G_{i i} P_{i}}{\sum_{j=1, j \neq i}^{N} G_{i j} P_{j} \delta_{c i c j}+n_{0}}
$$

Dimana $\mathrm{n}_{0}$ merupakan daya noise. Untuk melihat pengaruh daya pancar SU terhadap performa PU maka dilakukan pengukuran signal to interference ratio (SIR) pada PU.
Interferensi pada PU dapat disebabkan oleh daya yang dipancarkan transmitter PU yang lain dan daya dari SU di kanal yang sama. Perhitungan SIR pada penerima PU dapat diekspresikan dalam persamaan 3 .

$$
\gamma_{\mathrm{i}}^{\mathrm{pu}}=\frac{\mathrm{G}_{i i}{ }^{\mathrm{pu} \mathrm{P}_{\mathrm{i}}{ }^{\mathrm{pu}}}}{\sum_{\mathrm{j}=1, \mathrm{j} \neq \mathrm{i}}^{\mathrm{N}} \mathrm{G}_{\mathrm{ij}}{ }^{\mathrm{pu}, \mathrm{su}} \mathrm{P}_{\mathrm{j}}^{\mathrm{su}} \delta_{\mathrm{cicj}}+\mathrm{n}_{0}}
$$

$\mathrm{G}_{\mathrm{ij}}{ }^{\mathrm{pu}}$ merupakan link gain pada penerima PU ke-i, $\mathrm{P}_{\mathrm{i}}{ }^{\mathrm{pu}}$ merupakan daya pancar PU ke-i. $\mathrm{G}_{\mathrm{ij}}{ }^{\mathrm{pu} \text {,su }}$ merupakan link gain antara transmitter SU ke-j ke receiver PU ke- $i$.

Jika SU berada pada satu kanal yang sama dengan PU, maka SIR pada SU dapat diekspresikan pada persamaan 4:

$$
\gamma_{i}^{s u}=\frac{G_{i i}{ }^{s u} P_{i}{ }^{s u}}{G_{i j}{ }^{s u, p u} P_{j}^{p u} \delta_{c i c j}+\sum_{j=1, j \neq i}^{N} G_{i j}{ }^{s u, s u} P_{j}^{s u} \delta_{c i c j}+n_{0}}
$$

Dimana $\mathrm{G}_{\mathrm{ii}}{ }^{\mathrm{su}}$ merupakan link gain antara pemancar SU ke$i$ dengan penerima SU ke-i, $\mathrm{P}_{\mathrm{i}}^{\mathrm{su}}$ merupakan daya SU ke- $i$. $\mathrm{G}_{\mathrm{ij}}{ }^{\text {pu,su }}$ merupakan link gain antara transmitter SU ke-j ke receiver PU ke- $i$; $\mathrm{P}_{\mathbf{j}}{ }^{\mathrm{pu}}$ merupakan daya PU ke-j.

Signal to Interference Ratio mempengaruhi besar throughput. Perhitungan nilai throughput didapat dengan menggunakan teori Shannon Capacity seperti pada persamaan 5 [2] [4].

$$
T=B \cdot \log _{2}(1+S I R)
$$

Dimana $B$ merupakan Bandwidth frekuensi. Untuk penyederhanaan, bandwidth pada penelitian ini tidak dipertimbangkan atau dengan nilai bandwidth sama dengan 1 Hertz.

\section{Hasil dan Analisis \\ 3.1. Pemilihan Kanal}

Kanal merupakan jalur komunikasi antara pemancar dan penerima. Dalam penelitian ini topologi yang dibuat adalah ad hoc topology. Jumlah kanal yang disediakan dalam pemodelan ini disesuaikan dengan jumlah PU. Pemilihan kanal PU dipetakan pada tabel 2. Keberadaan PU pada kanal yang sama dengan SU mempengaruhi performa dari PU dan SU. Keberadaan PU dapat memberikan interferensi bagi SU dan begitu juga sebaliknya. Untuk meminimalkan interferensi, digunakan metode pemilihan kanal, agar setiap pengguna dapat menempati kanal dengan interferensi minimum. Pada penelitian ini, diamati kinerja dari pemilihan kanal dengan pendekatan game theory. Untuk mengetahui kinerja dari pemilihan kanal dengan pendekatan game theory, dibandingkan performasi jaringan tanpa menggunakan pemilihan kanal game theory dan performasi jaringan dengan menggunakan pemilihan kanal game theory. 
Untuk mengamati karakteristik pemilihan kanal pada PU dapat dilihat pada tabel 2. Tabel 2 menunjukkan penggunaan kanal tanpa menggunakan metode pemilihan kanal game theory dengan jumlah PU sebanyak 30 pengguna. Tabel 2 menunjukkan kanal yang digunakan oleh setiap PU pada setiap iterasi. N1 menunjukkan PU ke1, N2 menunjukkan PU ke-2, dst. Pada iterasi awal (iterasi 0) PU ke-1 sedang menempati kanal 23, PU ke-2 menempati kanal 11, PU ke-3 menempati kanal 8 dan seterusnya. Setiap pengguna mendapatkan kanal masingmasing. Pemilihan kanal PU adalah tetap, kanal yang dipilih untuk PU akan tetap sama untuk setiap iterasi. Sehingga ketika iterasi pertama salah satu pengguna telah memilih kanalnya, maka sampai iterasi terakhir pengguna tersebut akan tetap di kanal tersebut. Karena jumlah kanal yang disediakan adalah sama dengan jumlah PU, maka tidak ada kanal yang tidak digunakan untuk PU. Kanal pada jaringan yang tidak menggunakan pemilihan kanal game theory dapat diamati pada tabel 3. Tabel 3 merupakan sampel pemilihan kanal SU dengan 20 SU dan 30 PU. Tabel 3 merepresentasikan posisi SU dalam menempati kanal pada setiap iterasi. Sebagai contoh pada tabel 3, SU ke-1 sedang menempati kanal 11, SU ke-2 sedang menempati kanal 28, SU ke-3 sedang menempati kanal 6 dan seterusnya. Pada jaringan yang tidak menggunakan pemilihan kanal game theory, ketika salah satu pengguna telah menempati salah satu kanal, pada iterasi keberapapun akan tetap di kanal tersebut. Pemilihan kanal tidak merata, terdapat satu kanal yang ditempati oleh beberapa SU. Pada tabel 3 dapat dilihat bahwa kanal 11 ditempati oleh pengguna ke-1 dan pengguna ke-10.

Tabel 2. Kanal pada tiap user

\begin{tabular}{|c|c|c|c|c|c|c|c|c|c|c|c|c|c|c|c|}
\hline Itera-tion & N1 & N2 & N3 & N4 & N5 & N6 & N7 & N8 & N9 & N10 & N11 & N12 & N13 & N14 & N15 \\
\hline 0 & 23 & 11 & 8 & 27 & 21 & 4 & 17 & 18 & 14 & 25 & 30 & 20 & 7 & 15 & 5 \\
\hline 1 & 23 & 11 & 8 & 27 & 21 & 4 & 17 & 18 & 14 & 25 & 30 & 20 & 7 & 15 & 5 \\
\hline 2 & 23 & 11 & 8 & 27 & 21 & 4 & 17 & 18 & 14 & 25 & 30 & 20 & 7 & 15 & 5 \\
\hline 3 & 23 & 11 & 8 & 27 & 21 & 4 & 17 & 18 & 14 & 25 & 30 & 20 & 7 & 15 & 5 \\
\hline 4 & 23 & 11 & 8 & 27 & 21 & 4 & 17 & 18 & 14 & 25 & 30 & 20 & 7 & 15 & 5 \\
\hline 5 & 23 & 11 & 8 & 27 & 21 & 4 & 17 & 18 & 14 & 25 & 30 & 20 & 7 & 15 & 5 \\
\hline 6 & 23 & 11 & 8 & 27 & 21 & 4 & 17 & 18 & 14 & 25 & 30 & 20 & 7 & 15 & 5 \\
\hline 7 & 23 & 11 & 8 & 27 & 21 & 4 & 17 & 18 & 14 & 25 & 30 & 20 & 7 & 15 & 5 \\
\hline 8 & 23 & 11 & 8 & 27 & 21 & 4 & 17 & 18 & 14 & 25 & 30 & 20 & 7 & 15 & 5 \\
\hline 9 & 23 & 11 & 8 & 27 & 21 & 4 & 17 & 18 & 14 & 25 & 30 & 20 & 7 & 15 & 5 \\
\hline 10 & 23 & 11 & 8 & 27 & 21 & 4 & 17 & 18 & 14 & 25 & 30 & 20 & 7 & 15 & 5 \\
\hline
\end{tabular}

Tabel 2. Kanal pada tiap user (Lanjutan)

\begin{tabular}{|c|c|c|c|c|c|c|c|c|c|c|c|c|c|c|c|}
\hline Itera-tion & N16 & N17 & N18 & N19 & N20 & N21 & N22 & N23 & N24 & N25 & N26 & N27 & N28 & N29 & N30 \\
\hline 0 & 19 & 13 & 16 & 3 & 24 & 28 & 9 & 22 & 12 & 6 & 10 & 29 & 2 & 1 & 26 \\
\hline 1 & 19 & 13 & 16 & 3 & 24 & 28 & 9 & 22 & 12 & 6 & 10 & 29 & 2 & 1 & 26 \\
\hline 2 & 19 & 13 & 16 & 3 & 24 & 28 & 9 & 22 & 12 & 6 & 10 & 29 & 2 & 1 & 26 \\
\hline 3 & 19 & 13 & 16 & 3 & 24 & 28 & 9 & 22 & 12 & 6 & 10 & 29 & 2 & 1 & 26 \\
\hline 4 & 19 & 13 & 16 & 3 & 24 & 28 & 9 & 22 & 12 & 6 & 10 & 29 & 2 & 1 & 26 \\
\hline 5 & 19 & 13 & 16 & 3 & 24 & 28 & 9 & 22 & 12 & 6 & 10 & 29 & 2 & 1 & 26 \\
\hline 6 & 19 & 13 & 16 & 3 & 24 & 28 & 9 & 22 & 12 & 6 & 10 & 29 & 2 & 1 & 26 \\
\hline 7 & 19 & 13 & 16 & 3 & 24 & 28 & 9 & 22 & 12 & 6 & 10 & 29 & 2 & 1 & 26 \\
\hline 8 & 19 & 13 & 16 & 3 & 24 & 28 & 9 & 22 & 12 & 6 & 10 & 29 & 2 & 1 & 26 \\
\hline 9 & 19 & 13 & 16 & 3 & 24 & 28 & 9 & 22 & 12 & 6 & 10 & 29 & 2 & 1 & 26 \\
\hline 10 & 19 & 13 & 16 & 3 & 24 & 28 & 9 & 22 & 12 & 6 & 10 & 29 & 2 & 1 & 26 \\
\hline
\end{tabular}

Tabel 3. Kanal SU tanpa pemilihan kanal menggunakan pendekatan game theory

\begin{tabular}{|c|c|c|c|c|c|c|c|c|c|c|c|c|c|c|c|c|c|c|c|c|}
\hline Itera-tion & N1 & N2 & N3 & N4 & N5 & N6 & N7 & N8 & N9 & N10 & N11 & N12 & N13 & N14 & N15 & N16 & N17 & N18 & N19 & $\mathrm{N} 20$ \\
\hline 0 & 11 & 28 & 6 & 15 & 27 & 16 & 25 & 1 & 26 & 11 & 3 & 15 & 8 & 19 & 17 & 3 & 9 & 14 & 22 & 11 \\
\hline 1 & 11 & 28 & 6 & 15 & 27 & 16 & 25 & 1 & 26 & 11 & 3 & 15 & 8 & 19 & 17 & 3 & 9 & 14 & 22 & 11 \\
\hline 2 & 11 & 28 & 6 & 15 & 27 & 16 & 25 & 1 & 26 & 11 & 3 & 15 & 8 & 19 & 17 & 3 & 9 & 14 & 22 & 11 \\
\hline 3 & 11 & 28 & 6 & 15 & 27 & 16 & 25 & 1 & 26 & 11 & 3 & 15 & 8 & 19 & 17 & 3 & 9 & 14 & 22 & 11 \\
\hline 4 & 11 & 28 & 6 & 15 & 27 & 16 & 25 & 1 & 26 & 11 & 3 & 15 & 8 & 19 & 17 & 3 & 9 & 14 & 22 & 11 \\
\hline 5 & 11 & 28 & 6 & 15 & 27 & 16 & 25 & 1 & 26 & 11 & 3 & 15 & 8 & 19 & 17 & 3 & 9 & 14 & 22 & 11 \\
\hline 6 & 11 & 28 & 6 & 15 & 27 & 16 & 25 & 1 & 26 & 11 & 3 & 15 & 8 & 19 & 17 & 3 & 9 & 14 & 22 & 11 \\
\hline 7 & 11 & 28 & 6 & 15 & 27 & 16 & 25 & 1 & 26 & 11 & 3 & 15 & 8 & 19 & 17 & 3 & 9 & 14 & 22 & 11 \\
\hline 8 & 11 & 28 & 6 & 15 & 27 & 16 & 25 & 1 & 26 & 11 & 3 & 15 & 8 & 19 & 17 & 3 & 9 & 14 & 22 & 11 \\
\hline 9 & 11 & 28 & 6 & 15 & 27 & 16 & 25 & 1 & 26 & 11 & 3 & 15 & 8 & 19 & 17 & 3 & 9 & 14 & 22 & 11 \\
\hline 10 & 11 & 28 & 6 & 15 & 27 & 16 & 25 & 1 & 26 & 11 & 3 & 15 & 8 & 19 & 17 & 3 & 9 & 14 & 22 & 11 \\
\hline
\end{tabular}

Kanal 15 ditempati oleh pengguna ke-4 dan pengguna ke12. Hal ini mengakibatkan interferensi yang lebih besar pada kanal yang ditempati oleh lebih dari satu SU, sehingga SIR dan total throughput-nya rendah jika dibandingkan dengan pemilihan kanal dengan pemilihan kanal menggunakan pendekatan game theory. Untuk 
pemilihan kanal dengan menggunakan pendekatan game theory dapat dilihat pada tabel 4.

Pemilihan kanal dengan menggunakan pendekatan game theory dapat dilihat pada tabel 4. Secara umum pemilihan kanal dengan menggunakan pendekatan game theory dapat berpindah kanal ke kanal yang interferensinya lebih minimal. Perpindahan kanal dilakukan pada iterasi selanjutnya jika masih terdapat kemungkinan kondisi yang lebih baik dari iterasi sebelumnya. Pada tabel 4 dapat dilihat untuk pengguna ke-1, terdapat perubahan kanal pada iterasi ke-1, dari kanal 11 menjadi kanal 29. Pengguna ke-4 mengalami perubahan kanal pada iterasi ke-4, dari kanal ke 15 menjadi kanal 20. Dengan adanya perubahan kanal, performasi PU dan SU menjadi berubah. Pada penelitian ini, perubahan performasi dapat dilihat dari SIR dan throughput.

\subsection{Throughput}

Throughput didapat dari persamaan 5. Dari persamaan tersebut didapat bahwa semakin tinggi nilai signal to interference ratio (SIR) maka semakin tinggi nilai throughput. Dalam penelitian ini, throughput dapat dilihat pada empat skenario, yaitu: a. Perhitungan throughput tanpa pemilihan kanal game theory dan tidak mempertimbangkan keberadaan PU.

b. Perhitungan throughput tanpa pemilihan kanal game theory dengan mempertimbangkan keberadaan PU.

c. Perhitungan throughput dengan pemilihan kanal game theory tanpa mempertimbangkan keberadaan PU.

d. Perhitungan throughput dengan pemilihan kanal game theory serta mempertimbangkan keberadaan PU.

Throughput dari keempat skenario yang dilakukan dapat dilihat pada gambar 2. Dari gambar 2 dapat dilihat bahwa nilai throughput jaringan SU tanpa pemilihan kanal yang menggunakan pendekatan game theory, baik tanpa mempertimbangkan keberadaan dari PU dan dengan mempertimbangkan keberadaan PU adalah tetap. Hal ini disebabkan karena pada jaringan tanpa menggunakan pendekatan game theory, tidak ada perubahan kanal. Dengan tidak ada perubahan kanal, nilai SIR pada setiap pengguna tidak mengalami perubahan. Salah satu parameter yang mempengaruhi nilai SIR adalah interferensi.

Tabel 4. Kanal SU dengan pemilihan kanal menggunakan pendekatan game theory

\begin{tabular}{ccccccccccccccccccccc}
\hline Itera-tion & $\mathbf{N 1}$ & $\mathbf{N 2}$ & $\mathbf{N 3}$ & $\mathbf{N 4}$ & $\mathbf{N 5}$ & $\mathbf{N 6}$ & $\mathbf{N 7}$ & $\mathbf{N 8}$ & $\mathbf{N 9}$ & $\mathbf{N 1 0}$ & $\mathbf{N 1 1}$ & $\mathbf{N 1 2}$ & $\mathbf{N 1 3}$ & $\mathbf{N 1 4}$ & $\mathbf{N 1 5}$ & $\mathbf{N 1 6}$ & $\mathbf{N 1 7}$ & $\mathbf{N 1 8}$ & $\mathbf{N 1 9}$ & $\mathbf{N 2 0}$ \\
\hline $\mathbf{0}$ & 11 & 28 & 6 & 15 & 27 & 16 & 25 & 1 & 26 & 11 & 3 & 15 & 8 & 19 & 17 & 3 & 9 & 14 & 22 & 11 \\
1 & 29 & 28 & 6 & 15 & 27 & 16 & 25 & 1 & 26 & 11 & 3 & 15 & 8 & 19 & 17 & 3 & 9 & 14 & 22 & 11 \\
2 & 29 & 28 & 6 & 15 & 27 & 16 & 25 & 1 & 26 & 11 & 3 & 15 & 8 & 19 & 17 & 3 & 9 & 14 & 22 & 11 \\
3 & 29 & 28 & 6 & 15 & 27 & 16 & 25 & 1 & 26 & 11 & 3 & 15 & 8 & 19 & 17 & 3 & 9 & 14 & 22 & 11 \\
4 & 29 & 28 & 6 & 20 & 27 & 16 & 25 & 1 & 26 & 11 & 3 & 15 & 8 & 19 & 17 & 3 & 9 & 14 & 22 & 11 \\
5 & 29 & 28 & 6 & 20 & 27 & 16 & 25 & 1 & 26 & 11 & 3 & 15 & 8 & 19 & 17 & 3 & 9 & 14 & 22 & 11 \\
6 & 29 & 28 & 6 & 20 & 27 & 16 & 25 & 1 & 26 & 11 & 3 & 15 & 8 & 19 & 17 & 3 & 9 & 14 & 22 & 11 \\
7 & 29 & 28 & 6 & 20 & 27 & 16 & 25 & 1 & 26 & 11 & 3 & 15 & 8 & 19 & 17 & 3 & 9 & 14 & 22 & 11 \\
8 & 29 & 28 & 6 & 20 & 27 & 16 & 25 & 1 & 26 & 11 & 3 & 15 & 8 & 19 & 17 & 3 & 9 & 14 & 22 & 11 \\
9 & 29 & 28 & 6 & 20 & 27 & 16 & 25 & 1 & 26 & 11 & 3 & 15 & 8 & 19 & 17 & 3 & 9 & 14 & 22 & 11 \\
10 & 29 & 28 & 6 & 20 & 27 & 16 & 25 & 1 & 26 & 18 & 3 & 15 & 8 & 19 & 17 & 3 & 9 & 14 & 22 & 11 \\
\hline
\end{tabular}

Ketika tidak terjadi perubahan kanal, besar interferensi adalah tetap. Berdasarkan persamaan 5, salah satu yang mempengaruhi throughput adalah SIR. Jika tidak terdapat perubahan nilai SIR, maka besar throughput untuk semua iterasi adalah sama. Pada pembahasan tentang pemilihan kanal tanpa pendekatan game theory, dijelaskan bahwa tanpa adanya pendekatan game theory, tidak ada perubahan kanal pada pengguna. Kanal yang ditempati akan tetap digunakan pada setiap iterasi. Sehingga nilai throughput akan tetap sama pada setiap iterasi. Pada jaringan tanpa pendekatan game theory, rata-rata throughput jaringan lebih besar ketika tanpa mempertimbangkan keberadaan PU. Rata-rata total thoughput pada jaringan tanpa pemilihan kanal game theory dan tanpa PU sebesar 20,28 bps sedangkan total throughput pada jaringan tanpa pemilihan kanal game theory dan dengan PU sebesar 13,83 bps. Hal ini disebabkan karena tanpa ada PU, tidak ada interferensi dari PU ke SU.

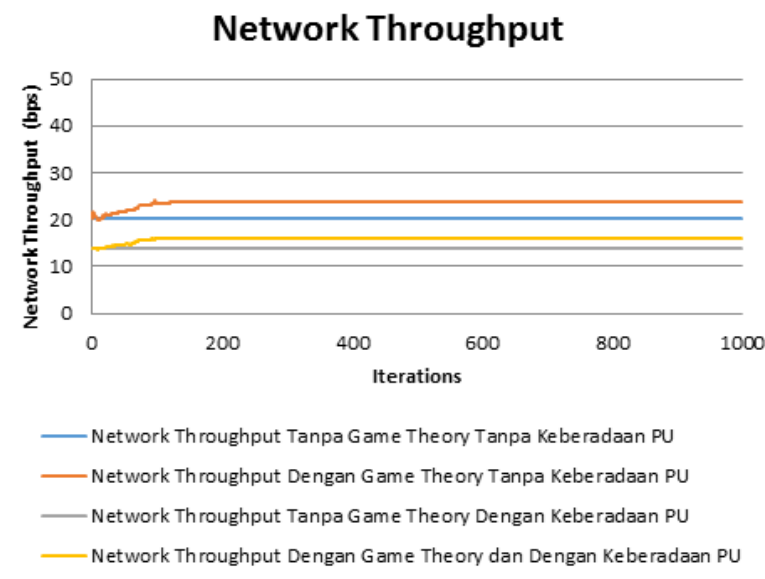

Gambar 2. Throughput jaringan SU tanpa pemilihan kanal game theory 
Pada jaringan yang menggunakan pemilihan kanal dengan pendekatan game theory dan tanpa PU, total throughput mengalami peningkatan dibandingkan dengan jaringan tanpa pemilihan kanal game theory dan tanpa PU. Pada jaringan yang menggunakan pemilihan kanal game theory tanpa PU, rata-rata total throughput sebesar 23,58 bps.

Pada jaringan yang menggunakan pemilihan kanal dengan pendekatan game theory dan dengan PU, total throughput mengalami peningkatan dibandingkan dengan jaringan tanpa pemilihan kanal game theory dan dengan PU. Pada jaringan yang menggunakan pemilihan kanal game theory dengan PU, rata-rata total throughput sebesar 15,87 bps.

Besar throughput pada jaringan dengan pemilihan kanal game theory yang tidak mempertimbangkan keberadaan PU lebih besar daripada jaringan yang mempertimbangkan keberadaan PU. Hal ini disebabkan karena pada saat memperhitungkan keberadaan PU, interferensi ke SU meningkat, yaitu interferensi dari sesama SU yang lain dan interferensi dari PU.

Pada jaringan yang menggunakan pemilihan kanal game theory, besar throughput mengalami perubahan, karena adanya perubahan kanal SU. Perubahan nilai throughput terjadi sampai pada iterasi tertentu. Dengan menggunakan game theory nilai throughput meningkat sampai pada kondisi terbaik, dimana tidak ada perubahan kanal lagi.

\subsection{Signal to Interference (SIR)}

Signal to Interference Ratio (SIR) merupakan nilai perbandingan daya yang dikirim dan interferensi. Pada penelitian ini, dianalisis nilai SIR dari PU maupun SU pada jaringan dengan pemilihan kanal yang menggunakan pendekatan game theory dan tanpa pendekatan game theory.

\section{CDF SIR PU}

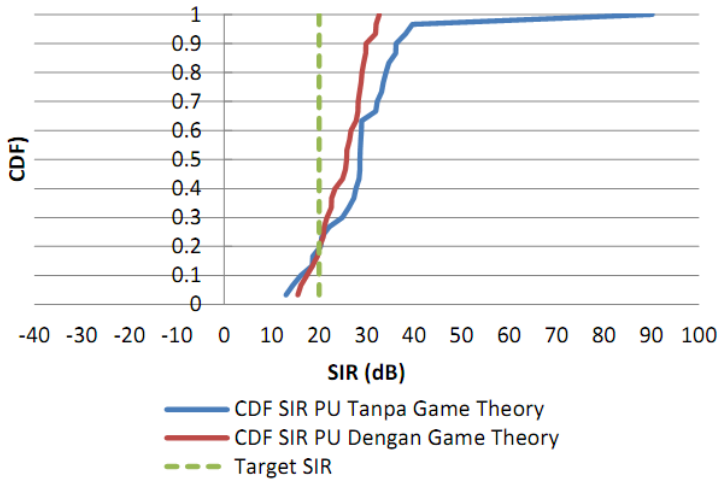

Gambar 3. CDF SIR PU pada jaringan yang menggunakan pemilihan kanal game theory dan tanpa menggunakan game theory

Gambar 3 menampilkan perbandingan Cumulative Distribution Function (CDF) SIR PU pada jaringan yang menggunakan pemilihan kanal game theory dan tanpa menggunakan game theory. Jika keberadaan PU dipertimbangkan, maka nilai SIR SU akan menurun jika dibandingkan dengan kondisi ketika keberadaan PU tidak dipertimbangkan. Dengan pemilihan kanal game theory, nilai SIR menjadi lebih tinggi dibandingkan tanpa menggunakan game theory, seperti ditunjukkan pada gambar 4 .

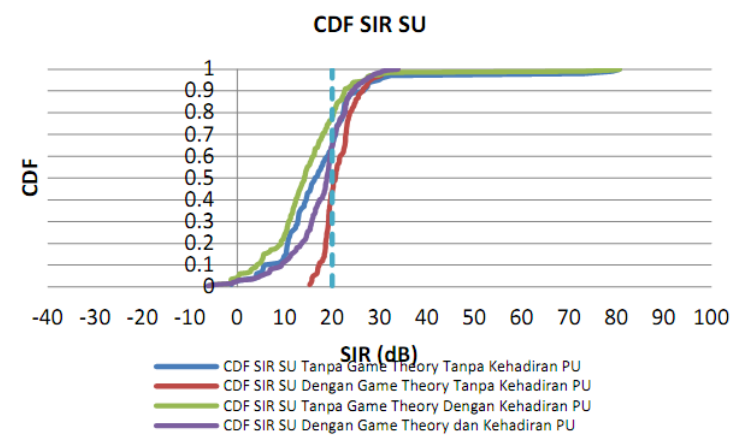

Gambar 4. CDF SIR SU pada jaringan yang menggunakan pemilihan kanal game theory dan tanpa menggunakan game theory

Tabel 5. Nilai rata-rata SIR

\begin{tabular}{lll}
\hline Skenario & & $\begin{array}{l}\text { Rata- rata SIR } \\
\text { (dB) }\end{array}$ \\
\hline \multirow{2}{*}{ Tanpa PU } & Dengan pendekatan Game theory & 21,4 \\
& Tanpa pendekatan Game theory & 18,01 \\
\hline \multirow{2}{*}{ Dengan } & Dengan pendekatan Game theory & 17,7 \\
PU & Tanpa pendekatan Game theory & 14,9 \\
\hline
\end{tabular}

Pada tabel 5 dapat dilihat nilai SIR SU pada jaringan yang menggunakan pendekatan game theory dan tidak menggunakan game theory, baik dengan keberadaan PU maupun tanpa keberadaan PU. Pada jaringan kognitif radio tanpa keberadaan PU, nilai rata-rata SIR dengan pendekatan game theory sebesar $21,4 \mathrm{~dB}$, sedangkan nilai SIR tanpa pendekatan game theory sebesar 18,08 dB. Pada jaringan radio kognitif dengan keberadaan PU, nilai SIR dengan pendekatan game theory sebesar $17,7 \mathrm{~dB}$, sedangkan tanpa pendekatan game theory sebesar 14,9 dB. Hal ini menunjukkan bahwa dengan pendekatan game theory, nilai SIR SU lebih besar dibandingkan dengan jaringan yang tidak menggunakan pendekatan game theory. Dengan keberadaan PU, nilai SIR SU lebih kecil dibandingkan dengan jaringan radio kognitif tanpa keberadaan PU.

\section{Kesimpulan}

Unjuk kerja jaringan radio kogntif dapat ditingkatkan dengan dengan menggunakan pemilihan kanal dengan pendekatan game theory. Pada jaringan radio kognitif tanpa keberadaan PU, nilai throughput tanpa pendekatan game theory PU sebesar 20,28 bps sedangkan dengan pendekatan game theory sebesar 23,58 bps. Nilai rata-rata SIR tanpa pendekatan game theory sebesar 18,08 dB sedangkan dengan pendekatan game theory sebesar 21,4 $\mathrm{dB}$. 


\section{Referensi}

[1]. J. Mitola and G. Q. Maguire, "Cognitive radio: making software radios more personal," in IEEE Personal Communications, 1999; vol. 6, no. 4, pp. 13-18.

[2]. Ian F. Akyildiz, Won-Yeol Lee, Mehmet C. Vuran, Shantidev Mohanty, NeXt generation/dynamic spectrum access/cognitive radio wireless networks: A survey, Computer Networks, 2006; Volume 50, Issue 13, Pages 2127-2159.

[3]. M. Alaydrus, "Cognitive Radio: Sistim Radio Cerdas," InComTech Jurnal Telekomunikasi dan Komputer, 2010; Vol 1, No 2.

[4]. O. Rioul, J.C. Magossi, "On Shannon's Formula and Hartley's Rule: Beyond the Mathematical Coincidence," Entropy, September 2014; pp. 4892-4910.

[5]. I. Sanjaya, A. Aziz, "Jaringan Radio Kognitif Sebagai Solusi Optimalisasi Penggunaan Spektrum Frekuensi Radio," Buletin Pustaka Telekomunikasi, Maret 2011; vol. 9, no. 1, pp. $93-112$.

[6]. I. W. Mustika, K. Yamamoto, H. Murata and S. Yoshida, "Spectrum Sharing with Interference Management for Distributed Cognitive Radio Networks: A Potential Game Approach," 2010 IEEE 71st Vehicular Technology Conference, Taipei, 2010; pp. 1-5

[7]. Beibei Wang, Yongle Wu, K.J. Ray Liu, Game theory for cognitive radio networks: An overview, Computer Networks, 2010; Volume 54, Issue 14, Pages 2537-2561.
[8]. A. B. MacKenzie and S. B. Wicker, "Game theory and the design of self-configuring, adaptive wireless networks," in IEEE Communications Magazine, Nov 2001; vol. 39, no. 11, pp. 126-131.

[9]. N. Amalia, Selo, I. W. Mustika,"Feasible Solution Kendali Daya dengan Keberadaan Pengguna Primer Pada Jaringan Radio Kognitif," Thesis, Yogyakarta: UGM, 2015.

[10]. D. Niyato, P. Wang and D. I. Kim, "Channel selection in cognitive radio networks with opportunistic RF energy harvesting," 2014 IEEE International Conference on Communications (ICC), Sydney, NSW, 2014, pp. 15551560 .

[11]. S. Sengottuvelan, J. Ansari, P. Mähönen, T. G. Venkatesh and M. Petrova, "Channel Selection Algorithm for Cognitive Radio Networks with Heavy-Tailed Idle Times," in IEEE Transactions on Mobile Computing, vol. 16, no. 5, pp. 1258-1271, May 12017.

[12]. Sharma, Uma, Poonam Mittal, and C. K. Nagpal. "Implementing game theory in cognitive radio network for channel allocation: An overview." International Journal of Energy, Information and Communications 6.2 (2015): 1722.

[13]. Mesodiakaki, Agapi, et al. "Performance analysis of a cognitive radio contention-aware channel selection algorithm." IEEE Transactions on Vehicular Technology 64.5 (2015): 1958-1972.

[14]. Nair, Gayathri R., Yamuna K. Moorthy, and Sakuntala S. Pillai. "A Survey on Dynamic Spectrum Sharing Using Game Theory in Cognitive Radio Networks." International Journal of Research and Engineering 3.8 (2016): 30-34. 